\title{
PEMETAAN PERUBAHAN KONDISI SOSIAL EKONOMI MASYARAKAT PASCA GEMPA BUMI DI KECAMATAN TANJUNG, KABUPATEN LOMBOK UTARA
}

\author{
Baiq Vidy Tiara Dewi*, Annisa Mu'awanah Sukmawati \\ Program Studi Perencanaan Wilayah dan Kota, Universitas Teknologi Yogyakarta \\ Jalan Glagahsari No. 63, Warungboto, Umbulharjo, Kota Yogyakarta 55164 \\ e-mail*: baiqvidytiaradewi@gmail.com
}

\begin{abstract}
ABSTRAK
Indonesia rentan terhadap bencana gempa bumi karena terletak pada garis Ring of Fire Samudera Pasifik. Gempa beruntun yang terjadi sejak 29 Juli 2018 menyebabkan banyak kerugian bagi masyarakat di Pulau Lombok. Gempa bumi dengan main shock berkekuatan 7,0 SR yang terjadi pada 5 Agustus 2018 memberi dampak kerusakan besar bagi Kabupaten Lombok Utara karena menjadi pusat gempa. Penelitian berlokasi di Kecamatan Tanjung karena mengalami dampak kerusakan terbesar serta merupakan salah satu pusat pemerintahan di Kabupaten Lombok Utara. Gempa bumi memberi dampak signifikan bagi aspek sosial dan ekonomi. Penelitian bertujuan untuk menilai dampak akibat bencana gempa bumi berdasarkan aspek sosial dan ekonomi di Kecamatan Tanjung Kabupaten Lombok Utara. Penelitian menggunakan metode penelitian kuantitatif dengan teknik analisis deskriptif kuantitatif dan pemetaan untuk menujukkan sebaran spasial daerah kerusakan. Pengumpulan data menggunakan metode observasi, wawancara, kuesioner, dan telaah dokumen. Jumlah sampel penelitian sebanyak 100 reponden dengan nilai error 10\% dengan teknik Proportionate Sampling yang disebar ke tujuh desa di Kecamatan Tanjung. Penelitian menunjukkan bahwa terdapat perubahan signifikan kondisi sosial ekonomi masyarakat sebelum dan setelah gempa bumi di Kecamatan Tanjung. Desa Jenggala menjadi desa dengan perubahan sosial ekonomi tertinggi atau paling rentan terdahap bencana gempa bumi. Perubahan sosial ekonomi diakibatkan oleh tingginya tingkat ancaman di desa tersebut. Selain itu, juga disebabkan oleh kerusakan infrastruktur, lamanya proses evakuasi, banyaknya korban, perubahan fisik lingkungan, serta karakteristik sosial ekonomi penduduk. Penelitian ini dapat menjadi acuan pemerintah daerah dalam menentukan upaya mitigasi terhadap bencana gempa bumi di Kecamatan Tanjung Kabupaten Lombok Utara.
\end{abstract}

Kata Kunci : dampak, sosial ekonomi, gempa bumi, Kabupaten Lombok Utara, Kecamatan Tanjung.

\section{ABSTRACT}

Indonesia is prone to earthquakes due to its location on the Ring of Fire in the Pacific Ocean. The successive earthquakes that occurred since July 292018 have caused a lot of losses on the Lombok Island. The earthquake with a 7.0 magnitude that occurred on August 52018 had a major impact on Lombok Utara Regency since it was the epicenter of the earthquake. This research is located in Tanjung Subdistrict because it suffered the greatest damage and one of the centers of government in the Lombok Utara Regency. Earthquakes have a significant impact on social and economic aspects. This study aims to assess the impact of the earthquake disaster based on social and economic aspects in Tanjung Subdistrict, Lombok Utara Regency. This research used quantitative research methods with quantitative descriptive and mapping analysis techniques to show the spatial distribution of the damaged areas. Collecting data using the method of observation, interviews, questionnaires, and document review. The number of samples was 100 respondents with an error value of $10 \%$ through the Proportionate Sampling technique which was distributed to seven villages in Tanjung Subdistrict. The research reveals that there are significant changes in the socio-economic conditions of the community before and after the earthquake in Tanjung Subdistrict. Jenggala Village has the highest socio-economic changes or the most vulnerable area of earthquake disasters. Socio-economic changes were caused by the high level of threats in this village. In addition, it is also caused by damage to infrastructure, evacuation time, the number of victims, physical environment changes, and characteristics of socio-economy. This research can be a reference for local governments in determining mitigation efforts against earthquakes in Tanjung Subdistrict, North Lombok Regency.

Keywords: impact, socio economi, eartquakes, Lombok Utara Regency, Tanjung Subdistrict.

\section{LATAR BELAKANG}

Indonesia berpotensi tinggi terhadap bencana gempa bumi. Hal ini dikarenakan letak Indonesia yang berada di garis Cincin Api (Ring of Fire) Samudera Pasifik. Pada tahun 2018,
Indonesia tercatat mengalami peningkatan sebesar 4.648 kali guncangan gempa bumi dibanding tahun sebelumnya (Umasugi, 2018). Peningkatan jumlah guncangan ini disebabkan oleh perlambatan rotasi bumi. Hal ini dapat menjadi tantangan baik bagi pemerintah maupun 
masyarakat di daerah terdampak. Salah satu peristiwa gempa bumi yang menimbulkan kerugian besar adalah yang terjadi di Pulau Lombok pada tahun 2018.

Pulau Lombok merupakan sebuah pulau yang terletak di Provinsi Nusa Tenggara Barat. Pulau lombok merupakan salah satu tujuan pariwisata unggulan di Indonesia. Gempa bumi yang terjadi di Pulau Lombok menjadi ancaman di tengah gencarnya upaya pemerintah dalam menarik kunjungan wisatawan di tahun 2019.

Pasca terjadinya main shock berkuatan 7,0 SR pada tanggal 5 Agustus 2018, Kabupaten Lombok Utara dikabarkan mengalami kerusakan dan kerugian terbesar. Berdasarkan data terakhir Badan Nasional Penanggulangan Bencana (BNPB) di tahun 2018, kerugian yang dialami Kabupaten Lombok Utara mencapai Rp 2,7 Triliun. Bencana ini tidak hanya berdampak dari segi ekonomi, namun juga mempengaruhi kondisi sosial masyarakat.

Beberapa penelitian menunjukkan bahwa gempa bumi berdampak signifikan bagi perubahan kondisi sosial dan ekonomi masyarakat. Seperti penelitian Fahlia et al. (2019) di Desa Mapin Rea, Kabupaten Sumbawa bahwa bencana gempa bumi mengubah kehidupan sosial dan ekonomi masyarakat karena masyarakat perlu beradaptasi kembali dengan lingkungannya dan pola kehidupan yang baru, seperti pendapatan, mata pencaharian, kebiasaan sosial. Muttalib \& Mashur (2019) dalam studinya di Kabupaten Lombok Utara juga menunjukkan bahwa kejadian gempa bumi mengubah kondisi produksi, distribusi, dan pola konsumsi masyarakat. Kerugian ekonomi dilihat dari hancurnya fasilitas, rumah-rumah, dan aset fisik lainnya dan berpotensi menimbulkan kemiskinan akibat perubahan struktural masyarakat. Sejalan dengan Jakandar (2019) pada studinya di Desa Kekait, Kabupaten Lombok Barat juga menemukan kerugian sosial yang banyak terjadi akibat gempa bumi, seperti hilangnya pendapatan untuk tiga kelompok masyarakat, yaitu wirausaha, petani, dan buruh. Aktivitas sosial kemasyarakatan dan interaksi sosial juga mengalami kerusakan akibat ketiadaan ruang untuk beraktivitas. Temuan Okwita (2015) mengenai dampak sosial juga menunjukkan bahwa pasca gempa, masyarakat menjadi cenderung individualis karena makin heterogennya masyarakat akibat kemunculan kelompok-kelompok masyarakat dan beragamnya mata pencaharian. Suwartana \& Anggarawati (2018) juga menunjukkan bahwa bencana gempa bumi juga berdampak pada sektor perekonomian, khususnya sektor ekonomi primer seperti pertanian dan perkebunan.
Pada skala global, gempa bumi juga memiliki dampak beragam bagi perekonomian, baik makro dan mikro, mapun kehidupan sosial. Penelitian Hosseini et al. (2013) di Iran menemukan bahwa kerusakan fisik, seperti bangunan dan infrastruktur tidak hanya menimbulkan dampak langsung namun juga berpotensi memicu dampak lainnya, seperti menurunnya pertumbuhan ekonomi dan investasi, pola konsumsi, sumber pendapatan, dan produksi. Shakya (2016) dalam studinya di Nepal juga menemukan gempa bumi berdampak signifikan bagi empat sektor, yaitu lintas sektoral (pemerintahan, lingkungan, ketenagakerjaan, keamanan sosial, dan gender), infrastruktur, sektor sosial (permukiman, kesehatan, pendidikan, dan kebudayaan), dan sektor produktif, seperti pertanian, industri, pariwisata, dan keuangan.

Besaran dampak gempa bumi dapat berbeda antara satu wilayah dengan wilayah lainnya. Ini disebabkan oleh konsentrasi populasi, keberadaan aktivitas esensial/ produktif, dan keberadaan aset fisik (Artiani, 2011; Hosseini et al., 2013). Kesiapsiagaan para pemangku kepentingan, baik pemerintah, masyarakat, dan swasta juga mempengaruhi dampak bencana yang mugkin ditimbulkan karena terkait dengan respon terhadap bencana (Tang et al., 2019).

Diperlukan upaya pemetaan sebaran daerah rawan gempa bumi untuk memperkirakan magnitude gempa serta potensi kerugian yang mungkin ditimbulkan sebagai strategi mitigasi bencana (Murtianto, 2016). Pada lingkup lokal/ mikro, perlu untuk mengaktifkan keberfungsian masyarakat, seperti fungsi keluarga dan kelompok masyarakat sebagai upaya mitigasi tingkat lokal (Maryam et al., 2008). Tara \& Baiquni (2013) juga menyatakan bahwa pemulihan kondisi masyarakat setelah gempa bumi dipengaruhi oleh tingkat kerusakan yang terjadi, aksesibilitas masyarakat baik ke fasilitas fisik maupun nonfisik, seperti bantuan pemerintah, dan perkembangan aktivitas masyarakat sebagai upaya bertahan hidup. Perlu peran aktif pemerintah dan masyarakat untuk mencari alternatif upaya-upaya menghidupkan kembali sosial dan ekonomi masyarakat karena kedua hal tersebut sering mendapat dampak signifikan akibat bencana (Rinawati \& Sukmawati, 2020).

Penelitian berlokasi di Kecamatan Tanjung, Kabupaten Lombok Utara. Lokasi ini dipilih karena merupakan wilayah yang mengalami kerugian terbesar akibat gempa bumi di Kabupaten Lombok Utara. Selain itu, juga merupakan salah satu kecamatan yang menjadi pusat pemerintahan di Kabupaten Lombok Utara. 
Kecamatan Tanjung memiliki tujuh desa (lihat Gambar 1) dan luas wilayah seluas $115,64 \mathrm{~km}^{2}$.

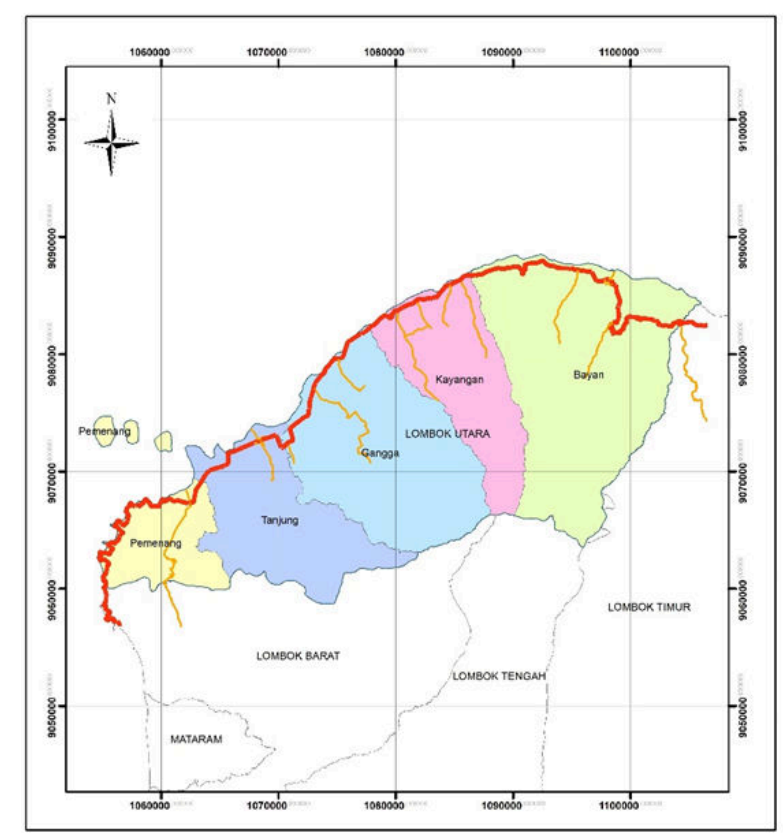

Gambar 1. Wilayah Administrasi Kecamatan Tanjung

Penelitian bertujuan untuk menilai dampak bencana gempa bumi berdasarkan aspek sosial dan ekonomi masyarakat di Kecamatan Tanjung Kabupaten Lombok Utara secara spasial. Pada analisis sosial, perubahan sosial dilihat dari jumlah aktivitas sosial yang dilakukan masyarakat. Penggunaan indikator ini dikarenakan jumlah aktivitas sosial menggambarkan prioritas masyarakat dalam memilih aktivitas sosialnya. Perilaku sosial merupakan perilaku yang terjadi dalam situasi sosial melalui cara orang berfikir, merasakan dan bertindak. Perubahan perilaku adalah perubahan tindakan, sikap atau pola respon seseorang terhadap situasi dan kondisi pada lingkungan sekitarnya (Ramadhani dalam Fahlia, 2019).

Dalam menentukan strategi mitigasi yang tepat, perlu untuk menilai tingkat kerusakan terdampak gempa secara komprehensif. Penelitian ini selain melihat perubahan kondisi sosial dan ekonomi, juga berupaya untuk memetakan sebaran spasial kerusakan, dimana belum banyak penelitian menggunakan aspek spasial untuk melihat dampak bencana. Padahal dampak bencana dapat berbeda antar wilayah tergantung dari karakteristik aktivitas serta sebaran konsentrasi penduduk maupun infrastruktur.

Penelitian ini dapat menjadi pertimbangan bagi pemerintah dalam membuat rencana terkait pemulihan pasca bencana di Kecamatan Tanjung, berupa perbaikan lingkungan, rehabilitasi, rekonstruksi, dan pemulihan sosial psikologis.
Upaya mitigasi ini dapat menjadi bentuk upaya dalam mendorong kembali kondisi sosial dan ekonomi di Kecamatan Tanjung dan wilayah terdampak bencana lainnya.

\section{METODE}

Penelitian menggunakan metode penelitian kuantitatif. Menurut Sugiyono (2017), metode penelitian kuantitatif merupakan suatu cara yang digunakan untuk menjawab masalah penelitian yang berkaitan dengan data berupa angka dan program statistik. Metode ini dipilih karena penelitian bertujuan untuk menilai perubahan kondisi sosial dan ekonomi sebelum dan setelah gempa bumi dengan perhitungan statistik lalu mendeskripsikan keadaan yang terjadi.

Metode pengumpulan data yang digunakan adalah metode pengumpulan data primer dan sekunder. Pengumpulan data primer dilakukan dengan wawancara, kuesioner, dan observasi lapangan. Sedangkan pengumpulan data sekunder melalui telaah dokumen bersumber dari instansi terkait, yaitu BPBD Kabupaten Lombok Utara.

Pengambilan sampel dalam penelitian ini menggunakan teknik Proportionate Sampling atau sampling acak secara proporsional. Menurut Sugiyono (2017), teknik Proportionate Sampling merupakan teknik pengambilan sampel yang dilakukan apabila karakteristik populasi terdiri dari kategori, kelompok, atau golongan yang setara atau sejajar lalu ditentukan sampel secara proporsional berdasarkan jumlah populasi pada masing-masing karakteristik. Pemilihan metode sampling ini agar diperoleh jumlah sampel yang sesuai dengan proporsi jumlah penduduk pada tiap desa di Kecamatan Tanjung. Sampel tidak diambil berdasarkan kategori tertentu melainkan hanya perlu disesuaikan dengan proporsi jumlah penduduk yang bekerja dan tinggal pada tiap desa di Kecamatan Tanjung.

Total sampel penelitian sebanyak 100 responden dengan tingkat kesalahan 10\%. Sampel ini didapatkan dari Rumus Slovin dengan perhitungan:

\section{Keterangan:}

$$
n=\frac{N}{1+N(e)^{2}}
$$

$$
\begin{aligned}
n & =\text { Jumlah sampel/jumlah responden } \\
N & =\text { Jumlah populasi } \\
e & =\text { Presentase kelonggaran ketelitian } \\
& \text { kesalahan pengambilan sampel yang } \\
& \text { masih bisa ditolerir }
\end{aligned}
$$

$$
n=\frac{48.880}{1+48.880(0,1)^{2}}
$$




$$
\begin{aligned}
& n=\frac{48.880}{489,8} \\
& n=99,8 \approx 100 \text { orang }
\end{aligned}
$$

Dari total sampel tersebut, didistribusikan ke tujuh desa di Kecamatan Tanjung. Persebaran responden pada tiap desa terlihat di Tabel 1.

Tabel 1. Distribusi Sampel Penelitian

\begin{tabular}{clcc}
\hline No & \multicolumn{1}{c}{ Desa } & $\begin{array}{c}\text { Jumlah Penduduk } \\
\text { (Jiwa) }\end{array}$ & $\begin{array}{c}\text { Jumlah } \\
\text { Sampel }\end{array}$ \\
\hline 1 & Sigar Penjalin & 8.916 & 18 \\
2 & Teniga & 2.405 & 5 \\
3 & Tegal Maja & 5.449 & 11 \\
4 & Jenggala & 8.339 & 17 \\
5 & Tanjung & 8.300 & 17 \\
6 & Sokong & 10.346 & 21 \\
7 & Medana & 5.125 & 10 \\
Total & & $\mathbf{4 8 . 8 8 0}$ & $\mathbf{1 0 0}$ \\
\hline
\end{tabular}

Penelitian menggunakan teknik analisis deskriptif kuantitatif. Metode analisis pertama yang digunakan dalam penelitian ini adalah Uji Beda dengan menggunakan Paired Sample T-Test atau Uji Beda T. Siregar (2017) menyatakan bahwa uji ini digunakan untuk mengetahui ada tidaknya perbedaan nilai rata-rata antara dua kelompok data yang berpasangan, dimana satu sampel mendapat perlakuan berbeda dari dimensi waktu. Paired Sample T-Test mengidentifikasi terjadinya perubahan antara dua sampel yang berpasangan. Paired Sample T-Test digunakan dalam penelitian ini kareana untuk mengetahui pengaruh gempa bumi terhadap kondisi sosial ekonomi masyarakat. Data didapatkan dari hasil kuesioner kepada sampel dan hasil wawancara terkait sosial ekonomi masyarakat sebelum dan pasca terjadinya gempa bumi. Data yang digunakan merupakan data rasio yang melambangkan nilai sebenarnya dari hasil pengisian kuesioner.

Hasil Paired Sample T-Test ditentukan oleh nilai signifikansinya. Nilai ini kemudian menentukan keputusan yang diambil, dimana jika nilai signifikansi $<0,05$ maka terdapat perbedaan signifikan antara variabel awal dan variabel akhir. Apabila nilai signifikansi $>0,05$ maka terdapat perbedaan signifikan antara variabel awal dan variabel akhir.

Pada penelitian ini, dapat diinterpretasikan apabila nilai signifikansi $<0,05$ menunjukkan adanya perbedaan yang signifikan antara variabel awal (data sebelum bencana gempa bumi) dengan variabel akhir (data setelah bencana gempa bumi) yang artinya bahwa bencana gempa bumi mempengaruhi kondisi sosial dan ekonomi masyarakat. Sedangkan apabila nilai signifikansi $>0,05$ menunjukkan tidak terdapat perbedaan yang signifikan antara variabel awal (data sebelum bencana gempa bumi) dengan variabel akhir (data sesudah bencana gempa bumi) yang artinya bencana gempa bumi tidak memberi pengaruh pada kondisi sosial ekonomi masyarakat.

Setelah mengidentifikasi perubahan sosial ekonomi dengan menggunakan Paired Sample TTest, dilakukan analisis perubahan sosial ekonomi menggunakan metode pemetaan dengan software ArcGIS. Pemetaan ini bertujuan untuk mengklasifikasikan perubahan ekonomi pada tiap desa di Kecamatan Tanjung. Pengklasifikasian ini didasarkan pada nilai rata-rata perubahan sosial ekonomi masyarakat di setiap desa. Pengklasifikasian ini dibagi menjadi tiga kategori yaitu rendah, sedang, dan tinggi (Tabel 2). Pembagian kategori ini menggunakan Skala Likert. Berikut perhitungan pembagian tiga kategori tersebut:

$$
\mathrm{K}=1+3,3 \log n
$$

\section{Keterangan:}

$$
\mathrm{K}=\text { Banyaknya kelas/kategori }
$$$$
\mathrm{n} \quad=\text { Banyaknya indikator }
$$

sehingga

$$
\begin{aligned}
\mathrm{K} \quad & =1+3,3 \log 7 \\
& =1+2,79 \\
& =3,79 \approx 3
\end{aligned}
$$

Nilai dari masing-masing kategori didapatkan dari perhitungan mean, yaitu nilai ratarata perubahan sosial maupun ekonomi dari tiap desa yang terdapat di Kecamatan Tanjung.

Tabel 2. Klasifikasi Perubahan Sosial Ekonomi

\begin{tabular}{ccc}
\hline Kategori & $\begin{array}{c}\text { Perubahan Sosial } \\
\text { (Jumlah Kegiatan) }\end{array}$ & $\begin{array}{c}\text { Perubahan Ekonomi } \\
\text { (Rp) }\end{array}$ \\
\hline \multirow{2}{*}{ Tinggi } & $0,63-0,78$ & $\mathrm{Rp} 2.468 .520,00-\mathrm{Rp}$ \\
& & $3.252 .778,00$ \\
Sedang & $0,46-0,62$ & $\mathrm{Rp} 1.684 .260,00-\mathrm{Rp}$ \\
& & $2.468 .519,00$ \\
Rendah & $0,29-0,45$ & $\mathrm{Rp} 900.000,00-\mathrm{Rp}$ \\
& & $1.684 .259,00$ \\
\hline
\end{tabular}

Berdasarkan hasil perhitungan range berdasarkan kondisi perubahan sosial, desa dengan perubahan sosial dengan kategori rendah terjadi apabila perubahan jumlah aktivitas sosial sebanyak 0,29 sampai dengan 0,45 kegiatan. Desa dengan perubahan sosial kategori sedang apabila penduduknya kehilangan jumlah aktivitas sosial dari 0,46 sampai dengan 0,62 kegiatan. Sedangkan desa yang termasuk dalam kategori perubahan sosial tinggi apabila penduduknya mengalami kehilangan jumlah aktivitas sosial sebanyak 0,63 sampai dengan 0,78 kegiatan. 
Berdasarkan kondisi perubahan ekonomi, desa yang termasuk dalam kategori perubahan ekonomi rendah apabila rata-rata perubahan penghasil penduduknya antara $\mathrm{Rp} 900.000,00$ hingga Rp 1.684.259,00. Desa dengan perubahan ekonomi sedang jika rata-rata perubahan penghasilan penduduk sebanyak Rp 1.684.260,00 hingga Rp 2.468.519,00. Desa dengan perubahan ekonomi tinggi jika rata-rata perubahan penghasilan penduduknya antara Rp $2.468 .520,00$ sampai dengan $\mathrm{Rp} 3.252 .778,00$.

\section{HASIL DAN PEMBAHASAN}

\section{Gempa Bumi di Kabupaten Lombok Utara}

Kejadian gempa bumi di Kabupaten Lombok Utara menyebabkan infrastruktur dan rumah-rumah penduduk. Sebagian besar kejadian gempa bumi di Kabupaten Lombok Utara terjadi di bagian barat karena letak wilayah yang berada pada struktur sesar (inferred fault) di sekitar Daerah Malaka (Kecamatan Pemenang) dan sekitarnya. Kabupaten Lombok Utara yang juga berada di sekitar Pegunungan Rinjani juga sangat rentan terhadap bencana gempa bumi (Bakti, 2020).

Berdasarkan hasil telaah dokumen dari BPBD Kabupaten Lombok Utara (2019), mengacu pada risiko yang bisa ditimbulkan, maka indeks risiko gempa bumi paling tinggi berada pada wilayah-wilayah dengan kepadatan tertinggi, seperti di Kecamatan Tanjung, Gondang dan Pemenang perkotaan. Ancaman bencana gempa bumi di Kabupaten Lombok Utara dapat dilihat pada Gambar 2.

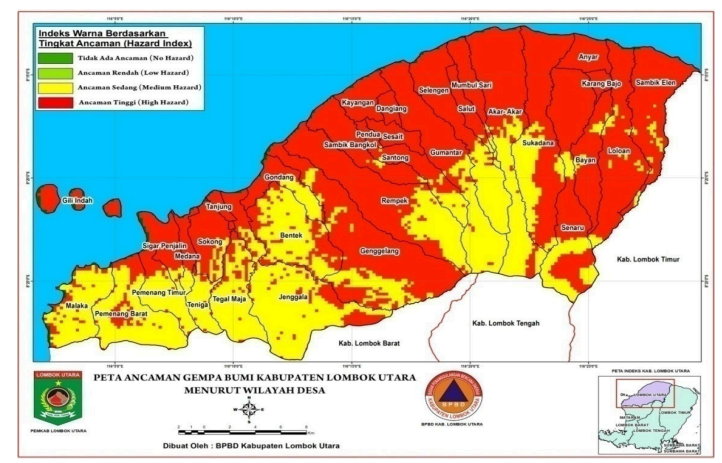

Gambar 2. Peta Ancaman Gempa Bumi Kabupaten Lombok Utara

Sumber: BPBD Kabupaten Lombok Utara (2018)

Berdasarkan sejarah kegempaan yang berhasil terekam oleh alat perekam gempa BMKG selama 10 tahun terakhir $(2008$ - 2017), wilayah Kabupaten Lombok Utara sangat rentan untuk terjadi gempa baik dengan magnitudo besar maupun yang tidak dirasakan. Wilayah perairan utara Pulau Lombok menjadi episenter beberapa kali kejadian gempa. Meskipun proses kegempaan itu didominasi oleh gempa yang tidak dirasakan, namun beberapa kali gempa dengan magnitude lebih dari 5 SR sempat terjadi di wilayah ini. Sejarah kegempaan di Provinsi Nusa Tenggara Barat (NTB) memang memang sudah terlihat sejak lama. Sejarah kegempaan di Provinsi NTB terlihat di Gambar 3.

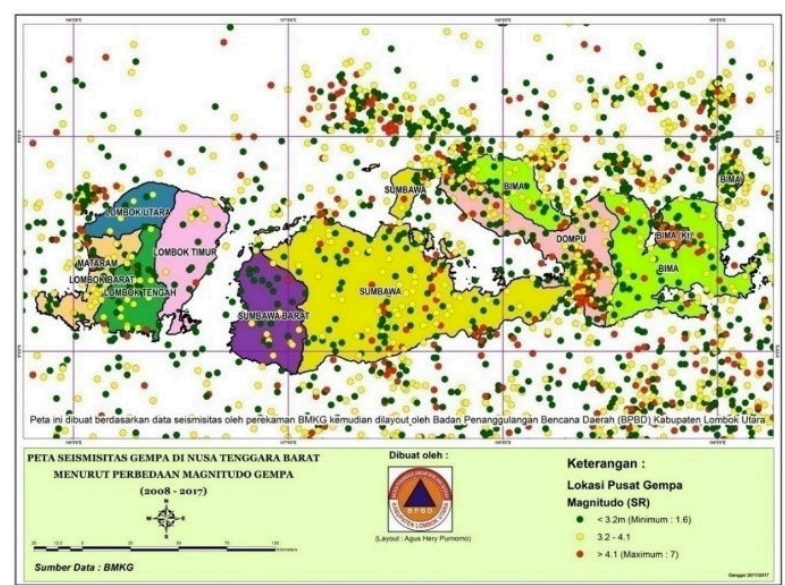

Gambar 3. Peta Seismik Gempa Bumi di Provinsi NTB menurut Magnitude (2008-2017) Sumber: BPBD Kabupaten Lombok Utara (2018)

Gempa bumi dikategorikan bermagnitudo rendah jika magnitudonya kurang dari 3,2 SR yang dilambangkan dengan titik hijau. Tergolong memiliki magnitudo sedang apabila memiliki magnitudo antara 3,2 SR hingga 4,1 SR dan dilambangkan dengan titik kuning. Tergolong memiliki magnitudo tinggi apabila magnitudonya di atas 4,1 SR hingga batas maksimum 7,0 SR dan dilambangkan dengan titik berwarna merah. Sejarah kegempaan yang dimiliki Provinsi Nusa Tenggara Barat menunjukkan bahwa tidak menutup kemungkinan apabila terjadi gempa bumi dengan magnitudo tinggi khususnya di Kabupaten Lombok Utara.

Gempa bumi dengan magnitudo 7 SR yang terjadi pada Minggu, 5 Agustus 2018 menimbulkan berbagai dampak seperti kematian, perubahan sosial ekonomi masyarakat dan daerah, serta kerusakan lingkungan. Tabel $\mathbf{3}$ menunjukkan data jumlah korban gempa bumi di Provinsi NTB. yang berpusat di Lombok Utara. Data pada Tabel 3 menunjukkan jumlah korban terbanyak terdapat di Kabupaten Lombok Utara. Sementara itu, total kerusakan dan kerugiannya akibat bencana gempa bumi di Kabupaten Lombok utara sebesar Rp 9.991.185.255.451,00 yang terdiri kerusakan sebesar Rp 5.479.211.198.187,00 dan kerugian sebesar $\mathrm{Rp}$ 4.511.974.057.264,00 (Tabel 4). 
Tabel 3. Jumlah Korban Gempa Bumi Tahun 2018 (Jiwa)

\begin{tabular}{lccccc}
\hline $\begin{array}{l}\text { Kabupaten/ } \\
\text { Kota }\end{array}$ & $\begin{array}{c}\text { Meninggal } \\
\text { Dunia }\end{array}$ & $\begin{array}{c}\text { Luka- } \\
\text { Luka }\end{array}$ & \multicolumn{3}{c}{ Mengungsi } \\
\cline { 5 - 6 } & 404 & 829 & 80.155 & 97.967 & 178.122 \\
\hline $\begin{array}{l}\text { Lombok } \\
\begin{array}{l}\text { Utara } \\
\text { Lombok }\end{array}\end{array}$ & 27 & 122 & 46.827 & 57.233 & 104.060 \\
$\begin{array}{l}\text { Timur } \\
\text { Lombok }\end{array}$ & 39 & 399 & 52.404 & 64.049 & 116.453 \\
$\begin{array}{l}\text { Barat } \\
\text { Lombok }\end{array}$ & 2 & 0 & 6.085 & 7.802 & 13.887 \\
$\begin{array}{l}\text { Tengah } \\
\text { Mataram }\end{array}$ & 9 & 63 & 8.503 & 10.391 & 18.894 \\
$\quad$ Total & $\mathbf{4 8 1}$ & $\mathbf{1 . 4 1 3}$ & $\mathbf{1 9 3 . 9 7 4}$ & $\mathbf{2 3 7 . 4 4 2}$ & $\mathbf{4 3 1 . 4 1 6}$ \\
\hline \multicolumn{1}{c}{ Sumber: } & & & & & \\
\hline
\end{tabular}

Sumber: Badan Nasional Penanggulangan Bencana (2018)

Perhitungan dampak bencana dinilai dari kerusakan dan kerugian pasca bencana terhadap sektor-sektor yang terdampak, meliputi sektor permukiman, infrastruktur, ekonomi produktif, sosial, dan lintas sektor. Hasil penilaian menunjukkan bahwa dampak terbesar dialami adalah di sektor permukiman sebesar $72,43 \%$ dan disusul sektor sosial sebesar 13,32\%. Besarnya kerusakan dan kerugian pada sektor permukiman sangat mempengaruhi sektor lainnya dalam rangka pemulihan. Secara rinci nilai kerusakan dan kerugian ditampilkan pada Tabel 4.

Persentase nilai kerusakan dan kerugian Kabupaten Lombok Utara berdasarkan sektornya terlihat pada Gambar 4. Sektor permukiman memiliki nilai kerusakan dan kerugian tertinggi dengan persentase $72,43 \%$.

Tabel 4. Nilai Kerusakan dan Kerugian akibat Gempa Bumi Tahun 2018 (dalam Rupiah)

\begin{tabular}{|c|c|c|c|}
\hline No & Sektor & Nilai Kerusakan & Nilai Kerugian \\
\hline 1 & Permukiman & 3.505 .485 .200 .000 & 3.731 .409 .800 .000 \\
\hline 2 & Infrastruktur & 303.676 .794 .062 & 15.943 .406 .000 \\
\hline 3 & Sosial & 1.160 .633 .995 .036 & 169.893 .013 .566 \\
\hline 4 & Ekonomi & 274.310 .973 .839 & 428.718 .820 .000 \\
\hline \multirow[t]{2}{*}{5} & Lintas Sektor & 235.104 .235 .250 & 166.009 .017 .698 \\
\hline & Total & 5.479.211.198.187 & 4.511.974.057.264 \\
\hline
\end{tabular}

Perbedaan antara nilai kerusakan dan kerugian pada sektor permukiman sangat signifikan dengan sektor lalinnya. Setelah itu, disusun dengan sektor sosial dengan persentase $13,32 \%$, kemudian sektor ekonomi produktif dengan persentase $7,04 \%$, lintas sektor dengan presentase $4,01 \%$, dan yang terakhir sektor infrastruktur dengan persentase $3,2 \%$. Kerugian pada sektor permukiman sangat tinggi dan dapat dilihat langsung dari banyaknya kerusakan permukiman warga di setiap desa.

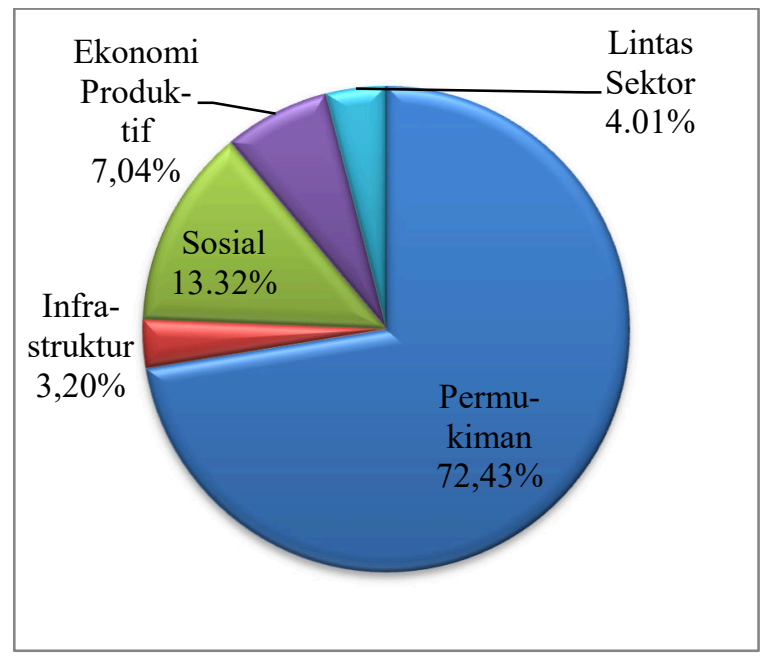

Gambar 4. Persentase Kerugian dan Kerusakan Tiap Sektor di Kabupaten Lombok Utara Sumber: BPBD Kabupaten Lombok Utara (2018)

Identifikasi Dampak Sosial dan Ekonomi Akibat Bencana Gempa Bumi di Kecamatan Tanjung

\section{Identifikasi dampak sosial}

Pada aspek sosial, uji Paired Sample T-Test yang dilakukan menggunakan variabel kegiatan sosial masyarakat di Kecamatan Tanjung. Peneliti mengidentifikasi kegiatan sosial yang dilakukan masyarakat dengan kuesioner. Indikator untuk menilai kegiatan sosial adalah frekuensi dilakukannya kegiatan sosial oleh masyarakat sebelum terjadinya bencana gempa bumi dikomparasikan dengan frekuensi setelah terjadinya gempa bumi. Dari pengkomparasian tersebut akan menghasilkan nilai signifikansi yang akan menunjukkan seberapa signifikan perubahan frekuensi dilakukannya kegiatan sosial oleh masyarakat di Kecamatan Tanjung. Hasil dari uji Paired Sample T-Test pada penelitian ini terlihat di Gambar 5.

\begin{tabular}{|c|c|c|c|c|c|}
\hline \multicolumn{6}{|c|}{ Paired Samples Statistics } \\
\hline & & Mean & $\mathrm{N}$ & Std. Deviation & $\begin{array}{l}\text { Std. Error } \\
\text { Mean }\end{array}$ \\
\hline \multirow[t]{2}{*}{ Pair 1} & sebelum & 89 & 100 & .751 &, 075 \\
\hline & sesudah & 62 & 100 & .632 & .063 \\
\hline
\end{tabular}

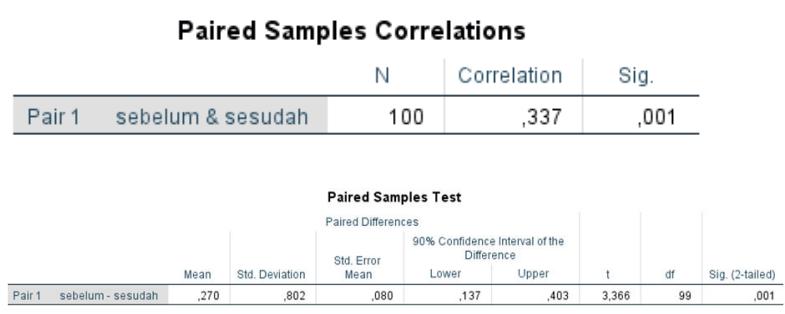

Gambar 5. Hasil Analisis Paired T-Test Perubahan Sosial di Kecamatan Tanjung 
Output perhitungan statistik di Gambar 5 dapat diinterpretasikan sebagai berikut.

1) Mean menunjukkan rata-rata jumlah kegiatan sosial yang dilakukan sampel. Pada penelitian ini diperoleh nilai mean 0,89 pada sebelum gempa bumi dan 0,62 pada sesudah terjadinya gempa bumi.

2) $N$ menunjukkan jumlah keseluruhan sampel yang berjumlah 100 penduduk yang tersebar di setiap desa di Kecamatan Tanjung.

3) Std. Deviation adalah standar deviasi atau simpangan baku yang menunjukkan keragaman atau variasi dari data yang diperoleh. Pada penelitian ini diperoleh standar deviasi 0,751 pada sebelum gempa bumi dan 0,632 pada setelah terjadi gempa bumi.

4) Correlation atau korelasi menunjukkan seberapa erat keterkaitan antara kedua variabel, yaitu kegiatan sosial sebelum dan sesudah gempa bumi. Pada penelitian ini menghasilkan korelasi sebesar 0,337.

5) Sig. atau signifikansi menunjukkan pengaruh yang ditimbulkan gempa bumi terhadap aktivitas sosial di masyarakat dengan nilai signifikansi 0,001 .

Kesimpulan dari hasil analisis Paired $T$ Test kondisi sosial tersebut adalah dengan nilai signifikansi sebesar 0,001 (mendekati 0) artinya terdapat perubahan yang signifikan antara kondisi sosial sebelum dan sesudah terjadinya gempa bumi di Kecamatan Tanjung. Bentuk perubahan sosial yang dimaksud berupa frekuensi aktivitas sosial yang dilakukan masyarakat yang mengalami penurunan atau terjadi perubahan jumlah aktivitas sosial masyarakat.

\section{Identifikasi dampak ekonomi}

Terkait aspek ekonomi, uji Paired Sample T-Test yang dilakukan menggunakan data penghasilan penduduk sebelum maupun sesudah terjadinya gempa bumi. Data penghasilan penduduk yang digunakan merupakan data penghasilan sebelum dan sesudah terjadinya gempa bumi lalu hasilnya dikomparasikan untuk melihat tingkat perubahan ekonomi masyarakat. Hasil pengkomparasian berupa nilai signifikansi yang menggambarkan besar perubahan perekonomian masyarakat seperti yang ditampilkan pada Gambar 6.

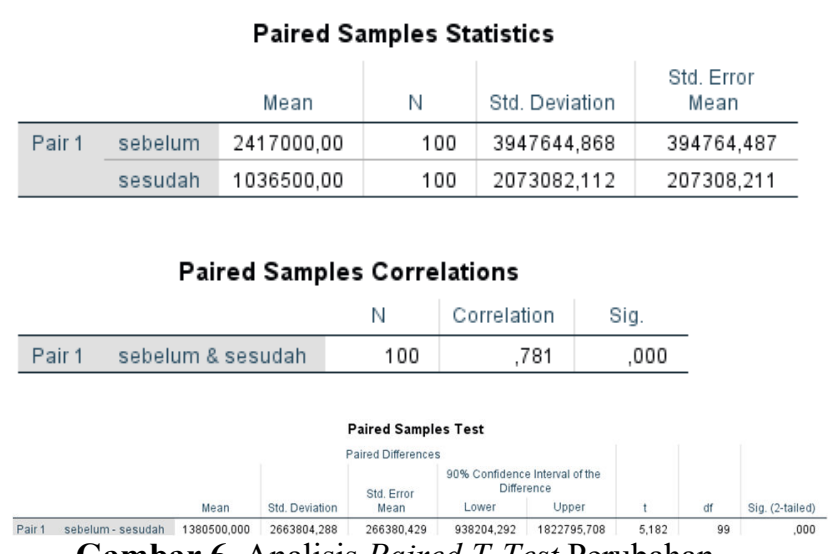

Gambar 6. Analisis Paired T-Test Perubahan Ekonomi

Berdasarkan Gambar 6, terdapat beberapa komponen yang dapat diinterpretasikan meliputi:

1) Mean menunjukkan rata-rata jumlah penghasilan yang dihasilkan sampel. Pada penelitian ini diperoleh nilai mean 2.417.000,00 pada sebelum gempa bumi dan $1.036 .500,00$ pada sesudah terjadinya gempa bumi.

2) $N$ menunjukkan jumlah keseluruhan sampel yang berjumlah 100 penduduk yang tersebar di setiap desa di Kecamatan Tanjung.

3) Std. Deviation adalah standar deviasi atau simpangan baku yang menunjukkan keragaman atau variasi dari data yang diperoleh. Pada penelitian ini diperoleh standar deviasi 3.947.644,868 pada sebelum gempa bumi dan 2.073.082,112 pada setelah terjadi gempa bumi.

4) Correlation atau korelasi menunjukkan seberapa erat keterkaitan antara kedua variabel yakni kegiatan sosial sebelum dan sesudah gempa bumi. Pada penelitian ini menunjukkan korelasi sebesar 0,781.

5) Sig. atau signifikansi menunjukkan pengaruh yang ditimbulkan gempa bumi terhadap aktivitas sosial di masyarakat. Pada penelitian ini menunjukkan signifikansi sebesar 0,000.

Kesimpulan dari hasil analisis data ekonomi masyarakat Kecamatan Tanjung tersebut berupa nilai signifikansi yang mencapai 0,000 (mendekati 0 ) yang menandakan bahwa perubahan ekonomi masyarakat di Kecamatan Tanjung sangat signifikan.

\section{Analisis Perubahan Sosial Ekonomi}

Berdasarkan hasil kuesioner masyarakat di Kecamatan Tanjung, perubahan sosial dan ekonomi dibagi menjadi tiga kategori yaitu rendah, sedang, dan tinggi. Pengkategorian tersebut berdasarkan pada nilai rata-rata dari data sosial dan data ekonomi yang diperoleh melalui survei primer dan form kuesioner. 


\section{Analisis perubahan sosial}

Pada analisis perubahan sosial, data yang dimanfaatkan adalah data jumlah kegiatan sosial yang dilakukan penduduk baik sebelum dan sesudah terjadinya gempa bumi. Data yang merupakan selisih dari jumlah aktivitas sosial yang dilakukan oleh tiap sampel dikelompokkan sesuai jumlah sampel yang telah diperoleh di tiap desa. Kemudian data tiap desa akan digunakan untuk menemukan nilai rata-rata (mean) dari selisih jumlah aktivitas sosial sebelum dan sesudah gempa bumi yang dilakukan oleh sampel. Mean dari perubahan sosial di tiap desa yang terdapat di Kecamatan Tanjung terlihat pada Gambar 7.

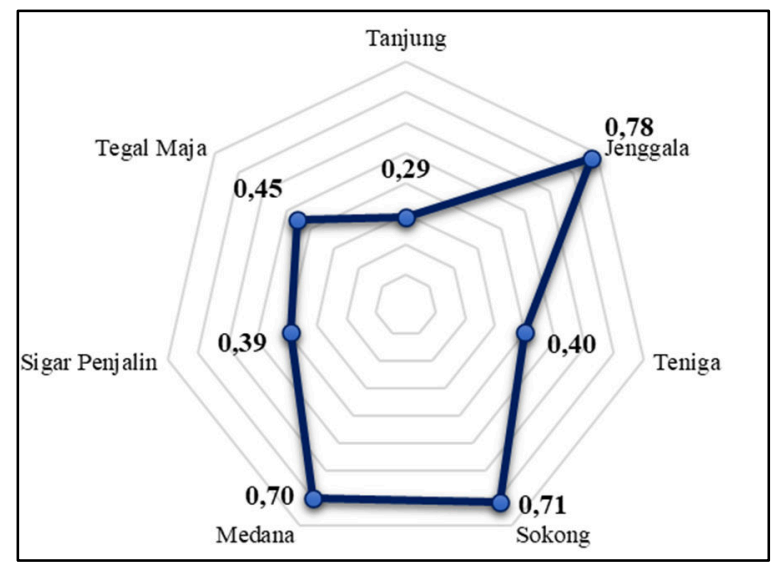

Gambar 7. Rata-rata Perubahan Sosial pada Tiap Desa di Kecamatan Tanjung

Diagram radar pada Gambar 7 memperlihatkan bahwa perubahan sosial tertinggi terjadi di Desa Jenggala. Sedangkan desa dengan perubahan sosial terendah adalah Desa Tanjung. Sementara itu, jika dilihat dari klasifikasi tingkat perubahan (kategori tinggi, sedang, rendah) yang dinilai berdasarkan range pada Tabel 2, hasil klasifikasi perubahan tiap desa di Kecamatan Tanjung berdasarkan jumlah aktivitas sosialnya dapat dilihat pada Gambar 8.

Gambar 8 menunjukkan bahwa desa yang mengalami perubahan sosial tinggi berada di Desa Jenggala, Medana, dan Sokong. Desa Medana menjadi desa dengan perubahan sosial tertinggi yakni dengan persentase mencapai $66,7 \%$ dari jumlah penduduknya. Sementara itu, sebanyak $61,1 \%$ penduduk Desa Jenggala mengalami perubahan sosial tinggi dan Desa Sokong juga mengalami perubahan sosial tinggi sebanyak $50 \%$.

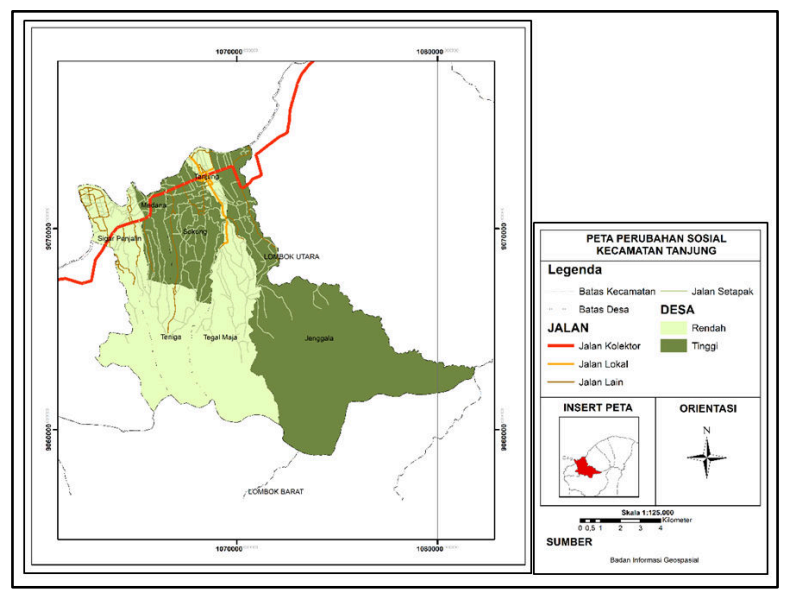

Gambar 8. Peta Perubahan Sosial di Kecamatan Tanjung

Perubahan sosial dapat dilihat secara nyata dengan berkurangnya kegiatan sosial yang dapat dilakukan masyarakat setelah terjadinya gempa bumi. Kegiatan sosial yang hilang berupa arisan dan pengajian. Berdasarkan Gambar 2 yang memperlihatkan Peta Ancaman Gempa Bumi Kabupaten Lombok Utara, hampir 100\% wilayah di Desa Medana dan Sokong memiliki tingkat ancaman tinggi sehingga menjadikan wilayah ini mengalami perubahan yang tinggi pada sektor sosial. Sedangkan Desa Sigar Penjalin, Tegal Maja, Tanjung,dan Teniga mengalami perubahan sosial dalam kategori rendah. Tidak terdapat desa yang masuk ke dalam kategori perubahan sosial sedang. Faktor yang mempengaruhi tingkat perubahan sosial baik pada tingkat rendah, sedang, dan tinggi diantaranya kerusakan infrastruktur, lamanya proses evakuasi, banyaknya korban, serta perubahan fisik lingkungan, tingkat pendidikan, pekerjaan, dan umur.

\section{Analisis perubahan ekonomi}

Dalam analisis perubahan ekonomi, data yang digunakan adalah data penghasilan penduduk sebelum dan sesudah terjadinya gempa bumi. Data ekonomi yang telah terkumpul berdasarkan desa yang terdapat di Kecamatan Tanjung kemudian dicari selisih antara penghasilan sebelum dan sesudah gempa bumi. Setelah ditemukan selisihnya, selisih penghasilan pada sampel di tiap desa dihitung sehingga ditemukan rata-rata (mean) dari selisih penghasilan di tiap desa antara sebelum dan sesudah gempa bumi. Rata-rata perubahan penghasilan di tiap desa terlihat pada Gambar 9. 


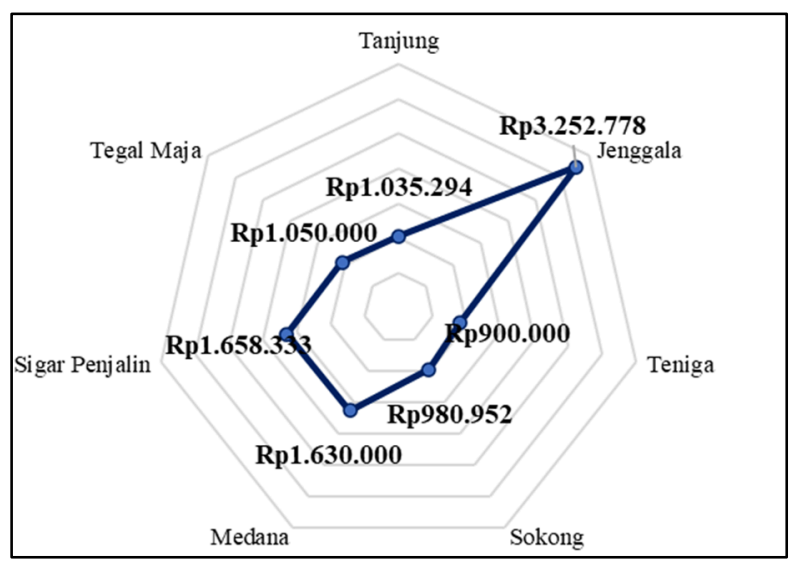

Gambar 9. Rata-rata Perubahan Penghasilan pada Tiap Desa di Kecamatan Tanjung

Desa yang mengalami perubahan ekonomi tertinggi adalah Desa Jenggala sebanyak Rp 3.252.778,00. Sedangkan desa dengan perubahan ekonomi terendah adalah Desa Teniga dengan perubahan sebanyak Rp 900.000,00. Setelah diketahui rata-rata dari selisih penghasilan sampel di tiap desa, kemudian diklasifikasikan menjadi rendah, sedang, dan tinggi sebagaimana yang telah dijelaskan pada range di Tabel 2. Hasil pengklasifikasian tiap desa di Kecamatan Tanjung berdasarkan perubahan ekonomi dapat dilihat pada peta di Gambar 10.

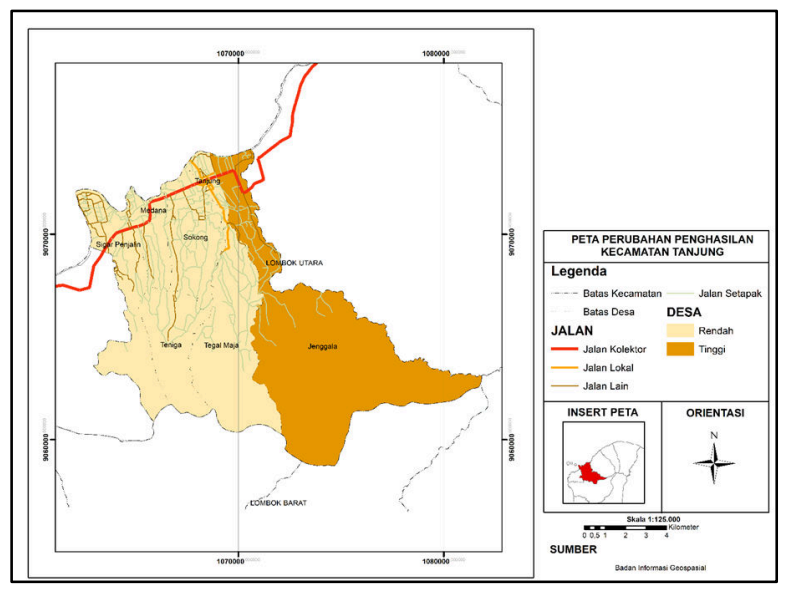

Gambar 10. Peta Perubahan Ekonomi di Kecamatan Tanjung

Pada peta di Gambar 10 dapat dilihat bahwa desa yang mengalami perubahan ekonomi tinggi hanya Desa Jenggala. Rata-rata perubahan penghasilan penduduk di desa ini mencapai $\mathrm{Rp}$ 3.252.778,00. Desa Jenggala merupakan desa yang penduduknya paling banyak mengalami perubahan mata pencaharian dibandingkan desa lainnya.

Mayoritas penduduk Desa Jenggala bermatapencaharian sebagai pedagang yang mana berubah menjadi pengangguran setelah terjadinya gempa bumi. Lamanya evakuasi, rehabilitasi, dan susahnya akses untuk keluar masuk barang menyebabkan masyarakat sulit untuk kembali menjalankan mata pencahariannya sebagai pedagang. Mata pencaharian memberi pengaruh terhadap penghasilan penduduk. Ketika terjadi perubahan mata pencaharian, mengacu pula pada perubahan penghasilan. Maka dari itu, Desa Jenggala juga menjadi desa dengan tingkat perubahan ekonomi yang paling tinggi dibandingkan desa lain yang terdapat di Kecamatan Tanjung. Kondisi mata pencaharian penduduk Kecamatan Tanjung sebelum gempa bumi terlihat pada Gambar 11.

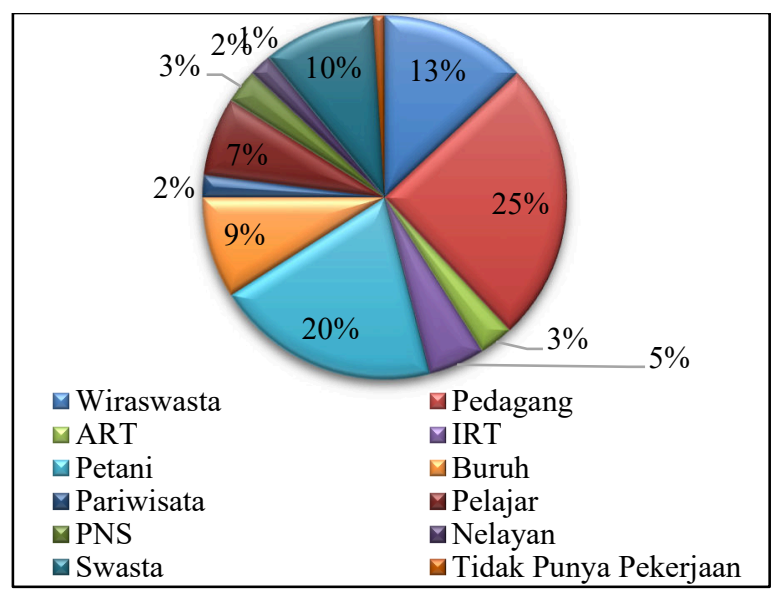

Gambar 11. Matapencaharian Penduduk Sebelum Bencana Gempa Bumi

Gambar 11 menggambarkan mengenai persentase mata pencaharian sebelum terjadinya gempa bumi. Terlihat bahwa mata pencaharian yang paling banyak adalah pedagang dengan persentase $25 \%$. Pada urutan kedua, sebanyak $20 \%$ penduduk bermatapencaharian sebagai petani. Sedangkan dengan persentase paling rendah adalah penduduk yang tidak memiliki pekerjaan dengan persentase $1 \%$. Sedangkan perubahan mata pencaharian penduduk setelah gempa bumi di Kecamatan Tanjung dapat dilihat pada Gambar 12.

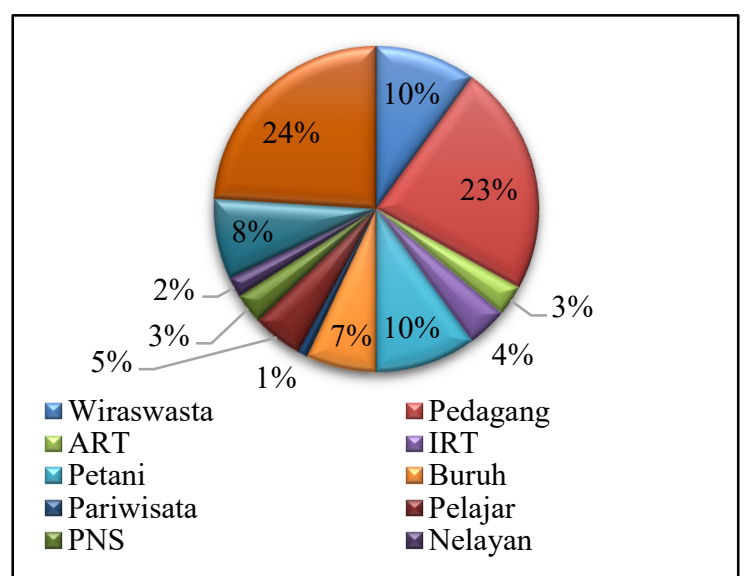

Gambar 12. Matapencaharian Sesudah Bencana Gempa Bumi 
Berbeda dengan sebelum terjadinya gempa bumi, dapat dilihat pada Gambar 12 bahwa jumlah mata pencaharian tertinggi adalah penduduk yang tidak memiliki pekerjaan dengan persentase $24 \%$. Terjadi peningkatan jumlah penduduk yang tidak memiliki pekerjaan dari yang awalnya memiliki persentase $1 \%$ hingga meningkat menjadi $24 \%$. Hal ini dipengaruhi oleh beberapa beberapa faktor diantaranya kerusakan sarana dan prasarana yang menyebabkan penduduk kehilangan mata pencahariannya. Hal ini juga disebabkan karena trauma yang dialami masyarakat sehingga tidak berani meninggalkan lokasi pengungsian yang kebanyakan berada di dataran tinggi dan jauh dari tempat bekerja. Taraf pendidikan juga berperan dalam hilangnya mata pencaharian penduduk. Kurangnya keterampilan menjadikan masyarakat sulit untuk mendapatkan pekerjaan baru.

Penduduk dengan mata pencaharian sebagai petani mengalami penurunan terbesar, yaitu mencapai $10 \%$. Jumlah penurunan ini diakibatkan trauma yang dialami masyarakat. Para petani mengaku takut untuk turun dari pengungsian untuk pergi ke sawah mengingat sesaat setelah terjadinya gempa bumi BMKG menginfokan bahwa peristiwa tersebut memiliki potensi tsunami.

Tidak hanya petani, trauma juga dialami oleh masyarakat yang bermatapencaharian lain, seperti pedagang, buruh, dan pekerja swasta. Penduduk dengan mata pencaharian sebagai pedagang berkurang sebanyak $2 \%$ yang menunjukkan bahwa sebagian besar penduduk yang bermatapencaharian sebagai pedagang terbilang mampu untuk melanjutkan pekerjaannya walaupun telah dilanda gempa bumi. Sebagian kecil pedagang yang tidak mampu melakukan pekerjaannya karena trauma.

\section{KESIMPULAN}

Berdasarkan hasil dari penelitian yang telah dilakukan, dapat ditarik kesimpulan bahwa bencana gempa bumi menimbulkan dampak perubahan sosial ekonomi yang signifikan bagi penduduk di Kecamatan Tanjung. Hal ini dapat dilihat dari hasil uji Paired Sample T-test yang menunjukkan angka signifikansi 0,001 untuk kondisi sosial dan signifikansi 0,000 untuk kondisi ekonomi yang berarti ada perubahan kondisi antara sebelum dan setelah bencana. Perubahan kondisi sosial dilihat dari hilangnya beberapa kegiatan sosial yang biasa dilakukan masyarakat, seperti arisan dan pengajian, dimana Desa Medana merupakan desa yang mengalami dampak perubahan sosial tertinggi, yaitu $66,7 \%$ dari total penduduknya dikarenakan tingginya tingkat ancaman bencana, kerusakan infrastruktur, lamanya proses evakuasi, banyaknya korban, perubahan fisik lingkungan, tingkat pendidikan, pekerjaan, dan umur. Sementara itu, jika dilihat dari kondisi ekonomii, Desa Jenggala adalah desa yang mengalami dampak terbesar perubahan ekonomi dengan rata-rata perubahan penghasilan penduduk mencapai $\mathrm{Rp} 3.252 .778,00$. Hal tersebut dikarenakan penduduk Desa Jenggala merupakan yang paling banyak mengalami perubahan mata pencaharian dibandingkan desa lainnya. Mata pencaharian pedagang dan petani paling banyak mengalami perubahan kondisi ekonomi. Hal ini disebabkan lamanya evakuasi, rehabilitasi, dan sulitnya akses keluar masuk yang menyebabkan masyarakat kesulitan untuk menjalankan kembali mata pencahariannya. Selain itu, faktor kualitas pendidikan juga menyebabkan sulitnya masyarakat dalam mencari pekerjaan baru setelah mata pencaharian yang semula terpaksa berhenti akibat gempa bumi. Kondisi wilayah yang luas dan bentuk topografi yang berbukit menghambat proses evakuasi dan rehabilitasi.

\section{PUSTAKA}

Artiani, L. E. (2011). Dampak Ekonomi Makro Bencana: Interaksi Bencana dan Pembangunan Ekonomi Nasional. Seminar Nasional Informatika 2011 (SemnasIF 2011), E67-E74.

Badan Penanggulangan Bencana Daerah Kabupaten Lombok Utara. (2018). Surat Keputusan Bupati Kabupaten Lombok Utara tentang Dokumen Rencana Aksi Rehabilitasi dan Rekonstruksi Pasca Bencana Gempa Bumi di Kabupaten Lombok Utara Tahun 2018 - 2019. Lombok Utara: Badan Penanggulangan Bencana Daerah Kabupaten Lombok Utara.

Bakti, H. K. (2020). Pemulihan Pasca Bencana Gempa Bumi di Lombok Utara Pada Tahun 2018 (Upaya Pemerintah Kabupaten Lombok Utara dalam Rehabilitasi dan Rekonstruksi). Universitas Muhammadiyah Yogyakarta.

Fahlia, F., Irawan, E., \& Tasmin, R. (2019). Analisis Dampak Perubahan Perilaku Sosial Ekonomi Masyarakat Desa Mapin Rea Pasca Bencana Gempa Bumi. Jurnal Ekonomi Dan Bisnis Indonesia, 4(1), 51-55. https://doi.org/10.37673/jebi.v4i1.362

Hosseini, K. A., Hosseinioon, S., \& Pooyan, Z. (2013). An investigation into the socioeconomic aspects of two major 
earthquakes in Iran. Disasters, 37(3), 516535. https://doi.org/10.1111/disa.12001

Jakandar, L. E. (2019). Dampak Gempa Bumi Lombok Terhadap Kondisi Sosial Ekonomi Masyarakat Di Desa Kekait Kecamatan Gunung Sari Kabupaten Lombok Barat. Sophist: Jurnal Sosial Politik, Kajian Islam Dan Tafsir, 1(2), 210-227. https://doi.org/10.20414/sophist.v1i2.772

Maryam, S., Sukandar, D., Guhardja, S., Asngari, P. S., \& Sunarti, E. (2008). Analisis faktorfaktor yang mempengaruhi keberfungsian pasca gempa dan tsunami di Nanggroe Aceh Darussalam. Media Gizi \& Keluarga, 32(2), 40-51.

Murtianto, H. (2016). Potensi Kerusakan Gempa Bumi Akibat Pergerakan Patahan Sumatera di Sumatera Barat dan Sekitarnya. Jurnal Geografi Gea, 10(1), 80-86. https://doi.org/10.17509/gea.v10i1.1667

Muttalib, A., \& Mashur. (2019). Analisis Dampak Sosial Ekonomi Masyarakat Pasca Bencana Gempa Bumi di Kabupaten Lombok Utara (KLU). Jurnal Ilmiah Mandala Education, 5(2), 84-91.

Okwita, A. (2015). Perubahan Kehidupan Sosial Ekonomi Masyarakat Pasca Bencana Gempa 30 September 2009 Nagari Gunung Padang Alai Kecamatan V Koto Timur Kabupaten Padang Pariaman. Jurnal Dimensi, 4(1), 117. https://doi.org/10.33373/dms.v4i1.32

Rinawati, R., \& Sukmawati, A. M. (2020). Penyelenggaraan Penanggulangan Bencana di Desa Kembang Kecamatan Pacitan Kabupaten Pacitan. Jurnal Tata Kota Dan Daerah, 12(1), 15-28. https://doi.org/10.21776/ub.takoda.2020.01 2.01.2

Shakya, K. (2016). Earthquake: Impact on Nepalese economy and women. Lowland Technology International, 18(2), 75-82.

Siregar, S. (2017). Statistik Parametrik untuk Penelitian Kuantitatif. Bumi Aksara.

Sugiyono. (2017). Metode Penelitian Kuantitatif, Kualitatif, dan R\&D. Alfabeta.

Suwartana, A. A. A. E., \& Anggarawati, B. S. (2018). Kondisi Sosial Ekonomi Petani Sebelum dan Setelah Bencana di Kabupaten Kepulauan Mentawai. Mahatani, 1(2), 153171.

Tang, R., Wu, J., Ye, M., \& Liu, W. (2019). Impact of Economic Development Levels and Disaster Types on the Short-Term Macroeconomic Consequences of Natural Hazard-Induced Disasters in China. International Journal of Disaster Risk Science, $\quad$ 10(3), 371-385. https://doi.org/10.1007/s13753-019-002340

Tara, A. M., \& Baiquni, M. (2013). Strategi Penghidupan Masyarakat Pasca Bencana Alam Gempa Bumi. Jurnal Bumi Indonesia, 2(1), 223-229.

Umasugi, R. A. (2018). Selama 2018, Gempa di Indonesia Meningkat 4.648 Kali Dibanding 2017.

https://megapolitan.kompas.com/read/2018/ 12/29/10303711/selama-2018-gempa-diindonesia-meningkat-4648-kali-dibanding2017 